\title{
Kültürlerarası Din Psikolojisi Açısından Kan Sembolizmi
}

\author{
Dr. Özer ÇETIN* \\ T.C. Ziraat Bankası Fen Lisesi / Balıkesir
}

\section{Özet}

İnsan çevresindeki bazı nesnelere sembolik anlamlar yüklemektedir. Tarihten günümüze kan bu nesnelerden birisi olmuştur. Kültürlerin çoğunda benzer şekilde kan sembolizmi görülmektedir Kan sembolizminde psikolojik, kültürel ve dinî faktörler etkin rol oynamaktadır. Kana biyolojik özelliklerinin dışında kutsallık, koruyuculuk ve arındırıcılık gibi sembolik anlamlar yüklenmektedir.

Ruhun kanda taşındığı inancı ve bazı kutsal metinlerdeki söylemler kanın kutsallaştırılmasına neden olmuştur. Kutsallaştırılmasından sonraki aşamada kandan yararlanma amaçlanmıştır. Korunma ve arınma duygusunun etkisiyle kişi kültürel çevrenin sunduğu kan ritüellerine yönelmektedir. Genel olarak kültürlerin çoğunda kan sürme ritüeli yaygın olarak kullanılmaktadır. Bu ritüel ile kandaki metafizik güçlerin sürülen yere aktarılması amaçlanmaktadır. Böylece onda var olduğuna

* Tel: +90 5056546913 E-posta: ozer.cetin@hotmail.com

(C) 2012 Kalem Eğitim ve Sağlık Hizmetleri Vakfı. Bütün Hakları Saklıdır. ISSN: 2146-5606 
inanılan güçlerin kan sürülen kişi veya nesneyi koruyacağı; kişiyi günahlarından arındıracağı umulmaktadır.

Anahtar Kelimeler: Kan; Kültürlerarası din psikolojisi; Korunma; Arınma; Ritüel; Sembolizm.

\title{
Blood Symbolism in Points of Crosscultural Psychology of Religion
}

\begin{abstract}
Human attributes the symbolic meanings to some objects in his environment. From past to today, one of these objects is blood. The symbolism of blood is seen similarly in most cultures. The psychological, cultural and religious factors play an active role at the blood symbolism. Except for biological characteristics, such as sacred, protection and purfication, symbolic meanings are attributed.

The belief that soul is carried in blood and some expressions at the holy texts caused blood to be made it holy. After this stage, it is aimed to get benefit from the blood. The effect of sense of protection and purification, individual tends to blood rituals that they are offered by cultural environment. Generally, blood sliding ritual is used commonly at the most cultures. The goal of this ritual is transfer the metaphysical forces on the point where it is overlooked blood on it. Thus, the powers that believed to be stocked in blood are hoped that they will protect the person or object and will purify the person from his sins.
\end{abstract}

Key Words: Blood; Crosscultural psychology of religion; Protection; Purfication; Ritual; Symbolism.

\section{Giriş}

Yaşadığımız çevredeki nesneler bizim için farklı anlamlar ifade eder. Nesnelere içinde yetiştiğimiz kültürel ortamın etkisiyle kazandığ1mız anlamların bizde oluşturduğu çağrışımlarla yaklaşırız. İnsanoğlu 
tarihten günümüze yaşadığı kültürel ortamdan etkilenme sonucu çeşitli nesnelere sembolik anlamlar yükleyerek onları farklı kılmıştır. Anlam yükleme olumlu veya olumsuz, bazen de aynı nesneye hem olumlu hem de olumsuz yönde olmuştur. Bu işleyişin en ileri safhası olarak olumlu anlamlar yüklenen nesneler kutsanmaya, olumsuz anlamlar atfedilenlerde ise lanetlenmeye kadar gitmiştir.

Sembolik anlamların yüklenmesinde toplumların üretim tarzları, kültür, din gibi faktörler belirleyici olmuştur. Bu süreçte etkin faktörlerin iş birliği içinde olması nesneye yüklenen sembolik anlamı güçlendirmiştir. Tarım toplumlarında üretilen mahsuller yaşamlarında önemli olması nedeniyle daha değerli görülmüştür. Hayvancılıkla geçinen toplumlarda hayvanlar ve onlardan elde edilen ürünlerden bazılarına önemli oldukları için daha olumlu anlamlar yüklenmiştir. Sembolik anlamların yüklenmesinde dinler etkin rol üstlenmişlerdir. Kutsal kitaplar ve din kurucularının yaklaşımları belirleyici faktörlerin başında gelmiştir. Dinî metinlerde nesnelere yaklaşım, din kurucularının söylemleri olumlu veya olumsuz sembolik anlamlar yüklenilmesine neden olmuştur. Müslümanlar Kur’an ve hadislerde haklarında olumlu söylemlerin olduğu nesnelere daha olumlu yaklaşmışlardır. Aynı durum diğer dinler için de geçerlidir. Örneğin İncil'de ekmeğin Hz. İsa'nın bedenini, şarabın ise kanını sembolize ettiğinin belirtilmesi üzerine Hristiyanlıkta şarap ve ekmeğe olumlu yaklaşılmıştır. Nesnelere sembolik yaklaşım hep olumlu yönde olmamıştır. Olumlu sembolik anlamlar yüklenildiği kadar olumsuz anlamlar da yüklenmiştir. Bütün kültürlerde ve dinlerde çeşitli nesnelere olumsuz anlamlar yüklenmektedir. Örneğin Kur’an’da olumsuz anlamlar yüklenmesi ve etinin yenmesi yasaklanan domuzla (Kur’an, 2:173; 5:3; 6:145; 16:115) 
ilgili olarak kültürümüzde lanetlemeye varan inanç ve tutumlar geliştirilmiştir. Üçüncü bir yöntem olarak ise nesnelere hem olumlu hem de olumsuz anlamlar yüklenmektedir. Örneğin ateşe hem arındırıcı hem de yakıcı, suya bir yönüyle canlılık, temizlik diğer yönden yıkıcılık yüklenmiştir (Fromm, 2003). Bunlardan birisi de kandır. Kan sembolizminde ikircikli bir yol izlenmiş olup olumlu anlamlar yanında olumsuz anlamlar da yüklenmiştir (Roux, 1987). Koruyucu, arındırıcı, sağaltıcı vb. olumlu anlamlar yanında tabulaştırıcı ve kirletici gibi olumsuz anlamlar da yüklenmiştir. Örneğin, Yahudi kültüründe hem "hayat verici" (Levililer, 17:11) hem de “toprağı kirletici” (Tekvin, 4:8-12) olarak görülmüştür. Yine farklı kültürlerde kadınların âdet kanına hem kirlilik hem de üretkenlik yüklenmiştir (Direk, 2003). Bu araştırmada farklı kültürlerde görülen olumlu yüklemeler ele alınacaktır.

Sembolik anlamların yüklendiği sıvı nesnelerin başında su, zeytinyağı, süt ve kan gelmektedir. Bunların en yaygın olarak görüleni ise kandır. Farklı kültürlerde benzer kan sembolizmine bağlı olarak ritüeller bulunmaktadır. Özellikle kan-kurban iş birliği sonucunda güçlü bir kan sembolizmi oluşmuştur. $\mathrm{Bu}$ nedenle kanlı kurbanlar zorluk derecesinin yüksek olduğu durumlarda kansız kurbanlara göre daha çok uygulanmıştır. Zorluk derecesinin az olduğu durumlarda kansız kurban türü daha sık uygulanmıştır. Zorlukların (savaş, kıtlık, doğal afetler vb.) şiddet derecesine göre hayvan ve hatta insan kanı akıtılarak yaşanılan sıkıntılarla baş edilmeye çalışılmıştır. İnsan kanının akıtıldığı durumların zorluk derecesi daha yüksektir. Zira zorluklar karşısında kullanılacak olan kanın da sembolik anlamının yüksek olması gerekir. Yaşanılan sıkıntılardan korunma- 
da olduğu gibi, elde edilen yeni firsatların kutlanmasında ve kutsanmasında da kana ihtiyaç duyulmuştur.

Kan uygulamalarında genel olarak iki tür davranış kalıbı bulunmaktadır. Birincisinde kanı akıtmama gayreti dikkat çekerken diğerinde ise kanı akıtma esastır. Birincisi daha çok Orta Asya kültürlerinde görülmektedir. Tarihte Türk, İran ve Moğol kültürlerinde görülen bu uygulama (Eröz, 1992), günümüzde ise Sibirya ve Altay yöresinde yaşayan Şamanist Türklerde görülmektedir. Mersin yöresinde yaşayan Tahtacılar üzerinde yapılan bir araştırmada bu uygulamanın tığlama yöntemiyle sürdürüldüğü, kanın bir kapta toplandığı ve toprağa düşmemesine, insanlara bulaşmamasına gayret gösterildiği tespit edilmiştir (Selçuk, 2004). Bu uygulama Cengiz yasalarına kadar girmiş, kan akıtarak hayvan boğazlama yöntemini uygulayanlar cezalandırılmıştır. Kan akıtmamak için hayvanın belini kırma, kafasına sert bir cisim vurma, karnını kalp üstünden yararak kalbi sıkma veya dışarıdan sokulan bir tığ ile kalbini delerek öldürme olan "tığlama" yöntemi kan akıtmamak için uygulanmış olan başlıca yöntemlerdir. Osmanlılarda görülen soylu kişilerin kanını akıtmadan öldürme yöntemleri bu uygulamanın devamı niteliğindedir (Turan, 1993). Türk ve Moğol kültüründe bir kişinin kanının akıtılarak öldürülmesi o kişinin aşağılandığını göstermekte olup genellikle adi suç işleyenlere uygulanırdı. Bu uygulamanın altında yatan neden birçok kültürde görülen ruhun kanda bulunduğuna dair olan inançtır (Roux, 2005). Bu yöntemle ruha saygı gösterilmiş, ondan gelecek olumsuzluklardan korunulmuş ve ondaki metafizik enerjinin kaybı önlenmiş olmaktadır. Aksi takdirde ruhun insanlara rahatsızlık vereceğine inanılırdı. İkinci ise kan akıtma yöntemidir. Bu yöntemle kanda var olduğuna inanılan güç açığa 
çıkartılıp çeşitli amaçlar için daha çok sürme yöntemiyle nesnelere aktarılmaktadır. Bu uygulama eski Misır, Asur, İbrani, Anadolu uygarlıklarında, Eski Latin Amerika, Eski Roma ve Yunan, İslâm öncesi Araplarda ve günümüzde çeşitli kültürlerde uygulanmaktadır. Kanın akıtıldığı kültürlerde kanın toprağa akmasıyla toprak ya tabulaşır ya da kutsallaşır (Frazer, 1991). Kan akıtma veya akıtmama uygulamaları farklılık arz etse de sonuç olarak benzerdirler. Çünkü her iki uygulamada kana sembolik bir değer atfedilmektedir.

\section{Teorik Yaklaşım}

Psikolojinin temel konularından birisi insan davranışları olduğu için ilk dönemlerden itibaren altında yatan faktörler üzerinde çalışmalar yapılmıştır. Araştırmacılara göre önem sırası değişse de çevrenin önemli faktörlerden birisi olduğu konusunda uzlaşı1mıştır. Bu nedenle çevre psikolojik çalışmalarda hep dikkate alınmıştır. Günümüzde ise çevre yerine “kültür” kavramının kullanımı giderek artmaktadır. Psikoloji ve kültür ilişkisi Herodot’a kadar uzanan bir geçmişe sahip olsa da bilimsel anlamda 19. yüzyılın sonlarında ilişkilendirilmiş, Wundt, Freud ve Jung çalışmalarında kültüre önem vermiş, 1980'li yıllardan itibaren ise kültür ve psikoloji arasında daha sıkı bir ilişki kurulmaya başlanmıştır (Triandis, 2007). Kültürün insan davranışları üzerinde belirleyiciliği tartışılsa da etkileyiciliği konusunda görüş birliği olması araştırmalarda kültürün dikkate alınması gereken bir faktör olarak değerlendirilmesine neden olmuştur. Çünkü her insan bir kültürel çevre içinde yetişmekte ve etkilerini bilinçli veya bilinçsiz olarak tutum ve davranışlarına yansıtmaktadır. Kültürel çevre dışında kalmış bir kişi düşünmek oldukça zordur. İçinde yaşadığı kültüre karşı tavırlar sergileyen marjinal gruplar bile bir yerde kül- 
türden -olumsuz yönde- etkilenmişlerdir. Ortak bir tanımı olmamakla (Kağıtcıbaşı, 2000) birlikte kültür, "bir topluluk tarafından paylaşılan ve kuşaktan kuşağa aktarılan inançlar, değerler ve davranışlar” (Keith, 2011) veya "bir grup tarafından paylaşılan yaşam biçimi” (Berry, 2002) olarak tanımlanabilir. Bu yaşam biçimi inançları, tutumları, değerleri, bazı model davranış kalıplarını ve insan üzerinde etkin birçok öğeyi kapsamaktadır. Birey, küçük yaştan itibaren yaşamaya başladığı sosyalleşme süreçleri ile bir yerde toplumda geçerli olan kültür tarafından belli ölçüde kodlanmakta ve bu durum yaşın ilerlemesiyle davranışlar üzerinde daha gözlenir hâle gelmektedir. Kültürün birey hayatının her alanında etkili olduğu hatta kültürel ortamdaki yaygın davranış biçimlerinin etkisiyle benzer kişilik yapılarının toplumda kümelendiği görüşü ağırlık kazanmaktadır. Örneğin son dönemlerde popüler bir konu olan "girişimcik" kültürel aç1dan ele alındığında girişimci kişiliklerin yetişmesinde kültürün önemli olduğu tespit edilmiştir (Aytaç, 2007). Kültürel yaklaşım psikoloji ile ilişkili psikiyatri (Göka, 2009) sosyal psikoloji, psikolojik danışmanlık ve rehberlik (Bektaş, 2006) gibi diğer alanlarda da giderek önem kazanmaya başlamıştır.

Psikolojide kültürün öneminin fark edilmesiyle "kültürel psikoloji” olarak adlandırılan bir bilim dalı kurulmuş ve kültürün insanın psikolojik ve sosyal hayatındaki fonksiyonları incelenmeye başlamıştır. $\mathrm{Bu}$ bakış açısı psikolojiye zenginlik katmış ve yeni araştırma alanları açılmıştır. Fakat bu çalışmalar belli bir kültür üzerinde gerçekleştiği için psikolojiye yöneltilen eleştiriler kültürel psikolojiye de yöneltilmiştir. Yöneltilen eleştirilerin başında çalışmaların evrensel bulgulara sahip olmaması ve belli bir kültürel çevreyle sınırlı kalması gelmektedir (Arnett, 2008). Bu 
açığı gidermek için bazı eleştiriler alsa da devreye farklı kültürlerde benzerliklerin ve farklılıkların bireyin psikolojik ve sosyal hayatındaki fonksiyonunu araştıran (Kağıtçıbaşı ve Berry, 1989) "kültürlerarası psikoloji” çabaları girmiştir. Kültürlerarası psikoloji çalışmalarına yönelik eleştirilerin başında, yapılacak çalışmalarda kullanılacak ölçeklerdeki kavramların farklı dillerde farklı çağrışımlar uyandırması, ortak ölçme araçlarını geliştirme zorluğu ve W.G. Sumner'in 1906 yılında yayımladığı Folkways:A Study of the Sociological Importance of Usages, Manners, Customs, Mores and Morals adlı eserinde ilk defa kullandığ 1 ethnocentrisim kavramının sonucu olarak önyargılı bakışın doğuracağı sakıncalar, her kültürel ortamın bir diğer ortamdan farklı olması nedeniyle bu çabaların yersiz kalacağı tezleri gelmektedir. Öncelikle şunu bilmeliyiz ki hiçbir kültürel ortam etkileşime kapalı değildir. Her kültür diğer kültürlerden bir şeyler alır ve onlara bir şeyler verir. Hiçbir etkileşimde bulunmamış, yalnızca geçerli olduğu toplum tarafindan geliștirilmiş bir kültür yoktur. Ayrıca her kültür içinde alt kültürler mevcuttur. Bir şehirde çok sayıda alt kültür olabilir. Bunlar da kendi içinde etkileşim hâlindedir. Farklı kültürler tarihte savaş, göç, ticaret (Pitirim, 1994) ve coğrafi yakınlık (Shiraev at all, 2010) gibi kanallarla etkileşirken günümüzde bunlara ilaveten globalleşen dünyada teknolojik imkânlar, internet, yazılı ve görsel medya, İngilizcenin dünya dili hâline gelmesi, ulaşım şartlarının kolaylaşması, turizmin yaygınlaşması gibi kanallar kültürlerarası etkileşimi hızlandırmıştır. Bu süreçte etkileşimi hızlandıran coğrafya faktörü eski etkinliğini kaybetmektedir. İngiltere'de aynı kasabada yaşayan Katolikler ile Protestanlar farklı kültüre sahipken bir başka Avrupa ülkesindeki mezhep mensuplarına kültürel açıdan daha yakın olabilmektedirler (Shiraev, 2010). Bu 
nedenlerle kültürlerarası psikolojiye yöneltilen eleştirilere karşı tezler ileri sürülebilir. Yapılan çalışmalar bazı psikolojik prensiplerin evrensel özellik taşıdığını ve kültürlerarası benzerliklerin farklılıklardan daha çok olduğunu göstermektedir (Keith, 2008). Farklı kültürlerde kişilik konulu yapılan çalışmalarda benzerlikler tespit edilmiş (Church, 2000), ergenler üzerinde yapılan kültürlerarası bir çalışmada ebeveynin, akran gurubu ve okulun etkili olduğu tespit edilmiştir (bkz. Scot ve Scot, 1988). Benzer bir çalışma din psikolojisi alanında yapılmış olup farklı kültürlerde dini gelişim sürecinde ebeveyn, akran ve okulun etkili olduğu görülmüştür (Ralph W. at all, 1996). Gümüş, Amerika ve Türkiye arasında yapmış olduğu kültürlerarası bir çalışmada değerler, kişilik, siyasal ideoloji gibi konularda benzerlikler tespit etmiştir (bkz. Gümüş, 2009). Bu tür çalışmalar genellenebilir psikolojik yasaların ortaya çıkmasına katkı sağlamaktadır. Ayrıca kültürlerarası psikoloji alanında yapılan çalışmalar yalnızca benzerlikleri değil farklılıkları da ortaya çıkarmayı amaçladığı için bilimsel açıdan kıyaslama yapma imkânı vermektedir (Berry, 2002).

Psikoloji alanındaki gelişmeler din psikolojisi çalışmalarına yansımaktadır. Günümüzde din psikolojisi araştırmalarında kültürel boyutun önemi vurgulanmaktadır (Belzen, 2002). Bu durum psikolojinin ilk y1llarını hatırlatmaktadır. İlk dönemlerde Wundt, Völkerpsychologie adlı eserinde dini, kültür içinde ele almış milletler psikolojisi içinde değerlendirmiştir (Triandis, 2007; Egemen, 1952). Freud, Totem ve Tabu ile Musa ve Tektanrıcılık adlı yapıtlarında kültürden hareketle psikanaliz yapmış (Köse, 2000), Jung tespit ettiği kültürlerarası benzerliklerden hareketle görüşlerini oluşturmuş̧tur. Fakat James'in dini bireysel bir olgu olarak değerlendirmesi (James, 1902) ve daha sonra Allport'un eserinin adından 
da (Individual and his Religion) anlaşılacağı gibi aynı yaklaşımı benimsemesi (Allport, 2004), Amerika'daki din psikolojisi çalışmalarının yönünü belirlemiştir. Gelişen süreçte Amerika kaynaklı çalışmaların merkezî bir konuma sahip olması ve diğer ülkelerdeki çalışmaları etkilemeleri neticesi din psikolojisi çalışmalarında bireysel yaklaşım ağırlık kazanmıştır. Dine bireysel yaklaşımı esas alan paradigmanın zafiyetleri zaman içersinde özellikle kültürlerarası çalışmaların önemini hissettirmiştir. Çünkü bulgular belli bir coğrafya ve din (özellikle Yahudi ve Hristiyan) bağlamında gerçekleştiği için genellenebilir özellik taşımamaktadırlar (Oman ve Thoresen, 2005). Bu nedenle yeterli özen göstermeden uyarlanan Amerikan din psikolojisi kaynaklı bulgular sıkıntılara yol açmaktadır. Zira bu çalışmalar henüz gelişme safhasındaki din psikolojisini güdümlü bir hale sokuştur. Dünyanın diğer bölgelerinde yapılan din psikolojisi çalışmalarının Amerika ve Batı merkezli çalışmaları referans almaları olumlu yönlerinin bulunmasının yanında bazı problemlere neden olmaktadır. Bu nedenle birçok araştırmacı çalışmaların kültürel bağlam içerisinde ele alınması gerektiği görüşünü ileri sürmeye başlamıştır (Belzen, 2002). Kültürel din psikolojisi ve kültürlerarası din psikolojisi çalışmalarının gerekliliği günümüzde yaygın olarak dillendirilse de bu çalışmaları yapmak için konuyu belirleme, araştırmacıların organizasyonu, uygulanacak yöntemlerin tespiti, önyargılardan arınma ve zaman gibi faktörler nedeniyle oldukça zor görünmektedir. Bütün bunlara rağmen bu tür araştırmaları gerçekleştirmek imkânsız değildir. En azından farklı kültürlerde yapılan çalışmalar sonucu birikmiş bulgular hakkında din psikolojisi açısından yapılacak analizler gelecekte gerçekleşmesi düşünülen kültürlerarası din psikolojisi çalışmalarına öncülük edebilir. Aynı 
konu ile ilgili olarak değişik kültürel ortamlarda birbirlerinden bağımsız yapılmış farklı bilim dallarına ait tarihî veya güncel veriler üzerinden benzerlik veya farklılıkların analizlerine dönük çalışmalar birtakım ipuçları verebilir. Ayrıca bu tür çalışmalar farklı disiplinleri bir konu etrafında toplayarak o konu hakkında daha geniş bir bakış açısı sağlayabilir. Sonuç olarak kültürlerarası din psikolojisi çalışmaları din psikolojisinin alanını genişletip zenginleştirerek globalleşen dünyadaki mevcut problemlerin çözümü konusunda din psikolojisinin önemini artıracaktır.

Bu çalışmada farklı din ve kültürlerdeki kan ritüellerinin altında yatan benzer psikolojik faktörler ve süreçlerin işleyişi ele alınmıştır. İnsandaki bazı duyguların kan sembolizmi ile ilişki olması onun psikolojik boyutunu oluşturmaktadır. Zira her insani yaşantıda psikolojik bir boyut oluğu gibi insan psikolojisi ile ilişkisi olmayan hiçbir şey onun yaşant1sında yer almaz. Kan sembolizminde psikolojik faktörler oldukça önemlidir fakat sosyolojik ve dinî faktörlerden bağımsız olmayıp onlarla iş birliği içindedirler. Makalenin amacı kan sembolizminin psikolojik boyutunun daha iyi anlaşılmasına katkıda bulunmaktır. Antik kültürlerde kan uygulamalarının yoğun olması ve bulguların fazla olması nedeniyle daha çok bu kültürler değerlendirmeye tabi tutulmuştur. Bunun yanında az da olsa eldeki veriler 1şığında günümüz kültürlerine değinilmiştir. Konu mitoloji, dinler tarihi, etnoloji, antropoloji ile yakından ilgili olduğu için bulgular bu disiplinlere ait kaynaklardan toplanmış ve din psikolojisine ait verilerle analizler yapılmıştır. Bu yönüyle araştırmada disiplinler arası bir yaklaşımla farklı kültürlerdeki benzer kan sembolizminden hareketle “kültürlerarası din psikolojisi” denemesine girişilmiştir. 


\section{Kan Sembolizmindeki Psikolojik Süreç}

Kan sembolizminin oluşmasındaki psikolojik süreç önce kana yüklenen kutsallık ile başlamaktadır. Birçok kültürde kanın kutsandığı görülmektedir. Kutsanmasından sonra ondan birtakım beklentilere girilmektedir. Burada insanın hayatında önemli bir yere sahip olan duygular aktif rol almaktadır. Bunların başında korunma ve suçluluk duygusu gelmektedir. İnsan, kendini güvende hissedip sahip olduklarını koruma, işlediği hatalar sonucu oluşan suçluluk duygusunun verdiği rahatsızlıklardan kurtulma arzusunda olan bir varlıktır. Kişi bu duyguların etkisiyle birtakım arayışlara yönelmektedir. Yetiştiği kültürel ortamın sunduğu davranış kalıpları arayışına cevap vermektedir. Birey korunma ve arınma arzusu ile yetiştiği kültürden öğrendiği birtakım ritüellere yönelmektedir. Bunlardan birisi birçok kültürde görülen kan ritüelleridir.

\section{Farklı Din ve Kültürlerde Kana Kutsallık Yüklenmesi}

Bazı mitolojik kaynaklarda kan tanrısal bir özelliğe sahip olup, insanın varoluşunda önemli bir yere sahiptir. Bu nedenle çoğu kez doğaüstü güçlerle ilişkilendirilmiştir. Sümerler tanrı Ea'nın hükmüyle damarları kesilerek öldürülen tanrı Kingu'nun kanıyla çamurun karışımından insanın yaratıldığına ve bu nedenle kanda tanrısal bir gücün varlığına inanmışlardır (Heidel, 2000). Misırlılar tan yeri kızıllığını gök tanrıçası Nuth'un güneş tanrısı Ra'yı doğururken kaybettiği kandan kaynaklandığına inanarak kanla gök tanrıçası arasında ilişki kurmuşlardır. Ayrıca eski Mısır kültüründe yaygın olan kan sürme âdetinde sürülen kan tanrının hakkı sayılmıştır. Benzer bir inanç İnka kültüründe olup kanın güneş tanrısı Uirakoşa'nın gıdası sayılmıştır (Feyizli, 2003). Latin coğrafyasın- 
daki kadim kültürlerde kralların tahtını kutsallaştırmak için üzerine kan serpilmesi kanın kutsal sayıldığına dair bir başka örnek olarak verilebilir.

Benzer inançları çağnıştırıcı yaklaşımlar Yahudilik ve Hristiyanlık için de geçerlidir. Hz. Musa kestiği kurbanın kanının bir kısmını mezbaha, bir kısmını İsrailoğullarının üstüne serperek: “...Işste bütün bu sözler konusunda Rabbin sizinle yaptığı ahdin kanı” demişti (Çıkış, 24:3-8). Bu ayetten kanın kutsallaştırıldığg sonucu çıkarılabilir. Zira Tanrı ile yapılan sözleşmenin sembolü olarak kan kullanılmış ve kan bir yönüyle Tanrı'yı temsil eder olmuştur. Ayrıca Tanrı'nın İsrailoğullarını korumak için Firavun’a verdiği dokuz beladan birisi kan belasıdır. "Harun asasını Firavun ve adamlarının gözü önünde nehre vurdu. Nehir kana dönüştü. Balıklar öldü, su koktu ve Mısırlılar suları içemedi. Mısır'ın her yerinde kan vardl.” (Çıkış, 7:20-21). Hristiyanlıkta ise Hz. İsa'nın Tanrı'nın oğlu olarak kabul edilip kanının şarapla sembolize edilmiş ve arındırıcı özellik yüklenerek kan kutsallaştırılmıştır (İbranilere Mektup, 9:22; I. Yuhanna, 1:7; Markos, 14:22-24).

Türk kültüründe de benzer bulgulara rastlanmaktadır. Kahramanların tanrısal bir işaretle dünyaya geldiklerine inanılırdı (Bekki, 20110). Tanrısal işaretlerden birisi kahramanların doğumunda ellerinde bulunan kan pıhtısıdır (Alptekin, 2009). Kan pıhtısı tanrısal bir işaret olduğu için kahramanın özel bir misyon için dünyaya gönderildiğinin belgesi sayılmıştır. İslâm sonrası yoğunluğu azalsa da kanın kutsallığına dair bazı bulgular görülmektedir. Örneğin bazı çevrelerde Hacı Bektaşi Veli’nin abdest alırken burnunun kanayıp abdest suyuna karışması sonrası ona hizmet eden Kadıncık Ana'nın bu suyu içerek hamile kaldığına inanılmaktadır 
(Gölpınarl1, 1995). Benzer bir durum Köroğlu ile ilgili olarak anlatılmaktadır. Köroğlu'na âşık olan Pikir kız ona oldukça yaşlı olduğu bir dönemde rastlamıştır. Ondan bir çocuk sahibi olmak için Köroğlu'nu öldürüp kanını içmiş ve içtiği kan nedeniyle hamile kalmıştır (Bayat, 2003). Bu anlatılara bakarak birtakım doğaüstü olayların kan üzerinden gerçekleştiği inancının altında kanın kutsallaştırılması yatmaktadır. Türk Mitolojisindeki kanın kutsallığı inancı (Kalafat, 2004), İslâm'1 kabulden sonra zayıflayarak da olsa devam etmiştir.

Sümer, Misır, Latin Amerika, Yunan, Ortadoğu, Orta Asya, eski Arap, Türk kültüründe ve günümüzdeki birçok kültürde kanın kutsandığg görülmektedir. Kanın kutsallaştırılmasının altında çeşitli nedenler yatmaktadır. Kültürlerin tümüne yakınında kan, ruhun barınağı ve hayatın kaynağı olarak görülmektedir. Eski Türk kültüründe suyun doğayı beslemesiyle kanın vücudu beslemesi arasında ilişki kurulmuştur (Mert, 2007). Canlılık veren ruhun kanda bulunduğuna dair inanç birçok kültürde görülmektedir. $\mathrm{Bu}$ inancın en dikkat çekici örneği Tevrat’ta geçen “Canlılara yaşam veren kandır.” (Levililer, 17:11) ayetidir. Metafizik alg1ların yaşadığımız dünyada görünür kılınması için kan aracı olarak kullanılmış (Öncül, 2010) ve kutsalın bazı nesnelerde tezahürü olarak tanımlanan hiyerofani (Eliade, 2000) oluşturulmuştur. Tanrısal özelliğe sahip olduğuna inanılan ruhun kanda taşındığına dair inanç kanın kutsallığına olan inancı daha da güçlendirmiştir.

Bazı kültürlerde görülen kan kardeşliği uygulaması da kanın kutsallaştırılmış olmasına örnek olarak gösterilebilir. Türk tarihinde İskitler’e kadar uzanan bir sözleşme türü olan kan kardeşliği (Durmuş, 2009) sözleşmesinde kutsal sayılan kanın kullanılması sözleşmeyi kutsallaştır- 
ma amacına yönelik olduğu, yine Yahudilikte Tanrı ile yapılan sözleşmede kullanılması kanın kutsandığını fikrini desteklemektedir.

\section{Korunma Duygusu ve Kan Sembolizmi}

\section{Korunma duygusunun insan hayatındaki yeri}

Korunma duygusu varlığımızın devamında önemli bir rol oynamaktadır. Anne karnında var olmaya adım attığımız cenin döneminden itibaren bu duygu davranışlarımız üzerinde etkili olur. Bu durum biyolojik yapımızda içgüdüsel olarak irademiz dışında çalışır. Hemeostatik denge bozulduğunda dengeyi tekrar tesis etmek için bir dizi işlem gerçekleşir. Dengenin bozulması varlığımızı tehdit ettiği için bu işleyiş kendiliğinden biyolojik varlığımızı korumaya dönük olarak devreye girer. Bazı davranışlarımız ise irademize bağlı olarak koruma amaçlı gerçekleşir. İnsanın varlığının kendi elinde olmaması, çevresinde gelişen olayların akışında kontrol yeteneğinin sınırlı olması, iç ve dış tehditler gibi nedenlere bağlı olarak hayat sahnesine adım atmasıyla birlikte varlığını kaybetme korkusu yaşar. Günlük hayatımızda kendi maddi ve manevi varl1ğımıza, yakınlarımıza, sahip olduğumuz objelere yönelik tehditler algıladığımızda korunma duygusunun etkisi ile irademiz dâhilinde davranışlar sergileriz. İnsan, kendini tehdit eden iç ve dış dünyasında geçen olaylar karşısında güven arayış1 içinde olduğu için (Hökelekli, 1993; Peker, 2003) tehditlerin oluşturduğu kaygı onu arayışa sevk etmektedir. Bu kaygılar yalnızca bireyin kendisi ile ilgili olmayıp, varlığının bağlı olduğu mikro çevresinden makro düzeydeki kozmolojik döngünün sürmesine kadar ilişkilidir. Güneşteki patlamalar, dünyaya çarpması muhtemel kuyruklu yıldızlar, dünyada görülen salgın hastalıklar, muhtemel nükleer savaşlar 
vb.ne kadar uzanmaktadır. İnsan bu tür tehditler karşısında kendisini koruyup güvende hissetmek ister. Çünkü onun varlığı biyolojisi ile olduğu kadar kozmoloji ile de yakından ilişkilidir. İnsan yaşamı boyunca varlığını sürdürürken bir yandan sahip olduklarını kaybetme kaygısını yaşar. Zira dış dünyada bu kaygıyı besleyen çok sayıda tehdit mevcuttur. Tüm bu tehditlerin oluşturduğu korku insanı rahatsız eder ve insanın korunma duygusunu tetikleyerek davranışlara sevk eder. Korunma duygusu bir yönüyle korku ile ilişkili bir duygu olup, sahip olduklarımızı kaybetme korkusu korunma duygusunu uyararak insanı sıkıntılı durumdan kurtulmaya dönük davranışlara yönlendirir. Bu duygu insanda negatif çağrışımlara neden olsa da varlığımızı sürdürmek için yararlı bir duygudur (Köknel, 1995). Yapılan araştırmalarda dinî hayatta korkunun günahlardan korunmanın yanında korku ile ilintili faktörlerin bireyleri ibadetlere sevk ettiği tespit edilmiştir (Hökelekli, 1983; Yaparel, 1987; Bayyiğit, 1989). Bazı Kur’an ayetleri bu tespitleri doğrular niteliktedir (Kur’an, 39:49; 10:12).

Din, insandaki korunma arzusunu tatmine yönelik özellik ve söylemlere sahiptir. Öncelikle insan cenin döneminden itibaren güvenli bir ortam ihtiyacı duymaktadır. Bebeklik döneminde kendini güvende hissetmek için bağlanma nesnesi geliştirir. Çocukluk yıllarında bu ihtiyacı anne-baba karşılarken daha sonraki yıllarda yeni bağlanma nesneleri keşfedilir. Bu süreçte din önemli bir rol oynar. Din insanın kendini güvende hissetmesi için birtakım söylemlerde bulunur. Söylemlerinin merkezinde ise Tanrı'nın varlığı bulunur. Tanrı'nın varlığına inanç insanda güven duygusunu pekiştirir. Bunların yanında tehditlerin az olduğu güvenli bir toplumsal hayat için bireylere bazı sorumluluklar yükler. 
Bireylerin dinî hayatındaki ibadetler de bir yönüyle insanın korunma arzusunu karşılar. Dinî ritüeller bireyin psikolojik hayatında güven duygusu geliştirmesi açısından önemli bir fonksiyona sahiptirler. Ritüelin amacı hakkında toplumsal birliği sağlama, belirsizlikleri giderme, krizi aşma vb. tezler ileri sürülmüştür (Spilka, 2005). Bu tezlerin hepsi bünyelerinde doğrudan veya dolaylı olarak korunmayı barındırırlar. $\mathrm{Bu}$ durum bireysel olarak yapılan ritüeller için de geçerlidir. Zekâtını veren bir Müslüman malının korunacağına, sadaka verdiğinde belalardan korunacağına inanır. Bunların yanında dualarında korunma amaçlı ifadeler kullanır. Bütün dinlere ait dua kitaplarını tarama imkânımız olsa günlük hayatta yaşanması muhtemel olaylardan korunmaya dönük duaların bulunduğunu tespit edebiliriz. İslâm dininde Esma-i Hüsna olarak bilinen Allah'ın isimlerinden birisi koruyan anlamına gelen "Hafız"dır. Bu durum diğer dinler için de geçerlidir. Kur'an dışındaki kutsal kitaplarda da Tanrı'nın koruyuculuğuna dair ayetler bulunmaktadır. $\mathrm{Bu}$ bağlamda insanın korunma arzusuna nihai olarak cevap verebilen yeryüzündeki tek kurum dindir.

Duygular haz ve korku temelli olup aksiyon ve reaksiyona neden olurlar. Kan ritüellerine neden olan duyguların yoğunluğu siradan olmayıp oldukça yoğundurlar Duygular yoğunlaştıkça bireyleri davranışlara yönlendirmeye başlamaktadır (Şentürk, 1997; Certel, 2003). Bu amaçla farklı kültürlerde bazı nesnelere koruyucu anlam yüklenerek beklentilere girilmiştir. Bunların başında kan gelmektedir. Kana kutsallık yüklendikten sonra korunma amaçlı bazı ritüeller gerçekleştirilmektedir. Korunma duygusunun yoğunluğunun birçok kültürde bireyleri kan ritüellerine yön- 
lendirdiğini görülmektedir. Bu ritüeller kozmolojik, toplumsal ve bireysel amaçlı olmak üzere üç başlık altında ele alınabilir.

\section{Kozmolojik döngünün korunmasına yönelik kan ritüelleri}

Kozmolojik döngünün devamı insan için büyük bir güvencedir. $\mathrm{Bu}$ döngü sayesinde belirsizlikler kaybolur. Bu nedenle güneş tutulması, kıtlık, tufan gibi kozmolojik döngünün sıra dışı durumlarında insanlar tedirgin olmuşlardır. Kozmolojik döngünün devamının güvencesi olarak tanrı/tanrılar görülmüş, bu döngünün tanrı/tanrıları yorduğu ve enerjilerini tükettiğine inanılarak tazelenmesi için kan sunulmuştur. Bu yöntemle kozmolojik döngü korunarak güvence altına alınmıştır. Bu tarz uygulamalarda özellikle insan kanı tercih edilmiştir. Çünkü en yüksek enerjinin insan kanında bulunduğuna inanılmıştır (Özkan, 2003). Kanının akıtılmasıyla ondaki enerji açığa çıkar ve tekrar tanrı/tanrılara döner. Böylece güçleri takviye edilmiş olur. Brahman kültüründe görülen ritüelinin temel amacı tanrıların enerjilerini takviye etmektir. Eski Mezopotamya kültürlerinde (Eliade, 1994), Fenikelilerde, bazı Kızılderili topluluklarda, eski Yunan kültüründe, Doğu Afrika yerlilerinde ve eski Ruslarda görülmüş olan çocuk kurbanları dikkat çekicidir. Doğumun tanrıların gücünü azalttığı düşünülür ve zafiyetini gidermek için ilk çocuk tanrının hakkı sayılıp boğazlanarak kanındaki enerji sunulurdu. İnka kültüründe ise güneş tanrısı Uirakoşa'nın kanla beslendiğine inanılır, O’na periyodik olarak düzenli bir şekilde kan sunulurdu. Böylece tanrıların korunması sayesinde kozmolojik döngü korunmuş olup devamlılık güvence altına alınmıştır. Zira yaratıcı konumundaki tanrıların kaybolan enerjileri takviye edilerek tazelenmiştir. Gücü tazelenmiş tanrıların yaratıcılığı sürdükçe kozmolojik döngü devam edecektir. 


\section{Bireysel ve toplumsal olarak korunma amaçlı kan ritüelleri}

Bir diğer benzer kan ritüelinde ise tanrılardan gelebilecek tehlikelere karşı korunma amaçlanmıştır. İnkalar beslenilmediği takdirde kendilerini cezalandıracağına inandıkları tanrıdan korunmak için sunu olarak kanı kullanmışlardır. Kendisinden korkulan tanrının kanla teskini sayesinde kendilerini güvenceye aldıklarına inanmışlardır. Benzer bir uygulama Slavlarda görülmüştür. Kadın görünümlü şer tanrısından korunmak için kestikleri kurbanların kanlarını etraflarına sürmüşlerdir (Kahraman, 1965). Kurban kanını sürme âdeti tarihte birçok toplumda vardı. Babil’de kurban kanı saray kapılarının üst ve yan sövelerine sürülürdü (Susa, 2005). Kan sürme âdeti Misır'da yaygın bir âdet olup, sürülen kan tanr1nın hakkı sayılırdı (Feyizli, 1993). Hakkı verilmediğinde tanrıdan gelecek cezalar söz konusu olduğu için bu uygulamanın da bir korunma yönü vardı. Tevrat'ta geçen bir ayetten anlaşılacağı üzere Tanrı, Musa ve kavmini korumak için firavunu kanla cezalandırmıştı (Çıkış, 7:20-21). Yahudiler Mısır'dan çıkış aşamasında evlerinde kuzu kesip kanını kapı sövelerine sürmüşlerdi (Budda, 2003). Bu uygulamanın bir nedeninin de kendilerini takip eden firavun ordusundan korunmak olduğu düşünülebilir. Zira bu süreçte onların en büyük arzuları firavundan korunmaktır. Yahudi tarihine bakıldığında kanın sembolik koruyuculuğunun çöl macerası süresince devam ettiği görülmektedir. Tevrat'ta geçen olay şöyle gerçekleşir: “Mısır'dan çıkışs sonrası çölde bir konaklama yerinde Rab Musa ile karşılaşır ve onu öldürmek ister. $O$ anda Sippora keskin bir taş alıp oğlunu sünnet ederek kanlı sünnet derisini Musa'nın ayaklarına sürer ve ona sen bana kanlı güveysin der. Bunun üzerine Rab Musa'yı esirger.” (Çıkış, 4:24-26). Sippora'nın Hz. Musa'nın ayaklarına kan sürmesi ve kanlı gü- 
veysin demesi sonrası Rab tarafindan esirgemesinde kanın sembolik olarak koruyucu özelliği öne çıkmaktadır. Eski Türk kültüründe kendisinden kötülük geldiğine inandıkları yer tanrılarına istemeyerek de olsa korunma amaçlı kan sunulurdu. Günümüzde eski Türk inanç ve uygulamalarını bünyesinde barındıran bazı Alevî topluluklarda korunma amaçlı kanlı kurban ritüeli sürdürülmektedir. Mersin yöresi Tahtacılarının ağaç kesim mevsimi geldiğinde ormandan gelecek kazalardan korunma amaciyla kanlı kurban ritüeli geleneğini devam ettirdikleri tespit edilmiştir (Selçuk, 2004).

Benzer uygulamalar Afrika kültüründe de görülmektedir. Bir Afrika toplumu olan Nuerlerde hayatın birçok bölümünde kanlı kurban ritüeli görülmektedir. Doğumda, hastalıkta savaş ve avlama öncesinde kanlı kurban ritüeli görülür (Pritchard, 1956). Felaketlerden ve tanrıların gazabından korunmak, muhtemel kötülükleri önlemek, hastalıktan ve uzun süren doğum sancısından kurtulmak için kanlı kurban ritüelinin sıklıkla uygulanması Afrika kültüründe de kanın koruyuculuğu ile ilgili inançların bulunduğu yönünde yorumlanabilir.

Kanın koruyuculuğu konusundaki inanç ve uygulamalar bazı araştırmacıların dikkatini çekmiş ve konuyla ilgili teoriler ileri sürülmüştür. Grardus van der Leew'a göre kanın akmasıyla kanda var olduğuna inanılan büyüsel güçler açığa çıkar ve bu enerjiden insanlar ve doğaüstü güçler beslenirler (Güç, 2003). Ülkemizde ise Daryal, kanlı kurban ritüelinde önemli olanın et değil kan akıtmak olduğunu ileri sürerek kan akıtmanın insanı şiddetten koruduğunu ileri sürmüştür (Daryal, 1980). İslâm dininde kanın koruyuculuğuna dair açık işaretler yoktur. Habil-Kabil kıssasında kanlı kurban ritüeli uygulamayan Kabil'in kendisini şiddetten koruya- 
maması gibi, Saffat suresinde Hz. İbrahim'in kıssası da bu doğrultuda yorumlanabilir. Kıssada Hz. İsmail yerine fidye olarak büyük bir kanlı kurban boğazlandığı belirtilir (Saffat, 37:107). Bu ayette geçen kurbanın kanlı olması ve Hz. İsmail'in korunması arasında ilişki kurulabilir. Ayrıca insanın yaratılmasına karşı meleklerin “...kan dökecek insan mı yaratacaksın..." (Kur’an, 2:30) cevaplarından korunmaya yönelik yorumlar yapılabilir. Bu yorumlara karşı Hac suresinde kesilen kurbanların kanlarının Allah'a ulaşmayacağının belirtilmesi (Kur’an, 22:37) ve din kardeşliğinin kan kardeşliğinden önce gelmesi kanın önemsizliği yönünde karşı tez olarak ileri sürülebilir.

\section{Hastalıklardan korunmaya yönelik kan ritüelleri}

Farklı kültürlerde kanın tedavi edici olduğuna dair inançlar ve uygulamalar bulunmaktadır. Misır firavunları kan banyosu yaparak ihtiyarlıktan korunduklarına inanmışlardır (Focus, 1997). Kanın tedavi edici ve koruyucu özelliği nedeniyle çeşitli toplumlarda sara tedavisi için kan banyosu yapılmıştır (Ferm, 1945). Roma'da yaralı gladyatörlerin sıcak kanını sara hastalarına tedavi amaçlı içirme (Conticelli, 2003), Avustralya yerlilerinde gençlerle yaşlıların kanlarını karıştırma âdeti bulunmaktadır. $\mathrm{Bu}$ uygulama ile gençlerin kanlarındaki enerjinin yaşlılara geçerek yaşl1ların daha dirençli olmasına katkı sağladığına inanılmaktadır. Benzer uygulama yeni doğan çocuklar için kesilen kurbanların kanını çocuğa sürme uygulamasında görülmektedir. Aynı uygulama İslâm öncesi Araplarda mevcut olup koruyucu olduğuna inandıkları kurban kanını çocuğun başına sürmüşlerdir (Ateş, 1996). 
Bu tür uygulamalar günümüzde ülkemizin bazı yörelerinde devam etmektedir. Çeşitli yörelerde kurban kanı nefes darlığı olanlara, alkoliklere, iştahsızlara şifa amaçlı içirilmekte ve meyve vermeyen ağaçlara sürülmektedir (Erginer, 1997). Benzer bir uygulama ise Karapapah Türklerinde, Irak Türkmenlerinde ve Türkmenistan’da görülmektedir. Karapapah Türkleri "Kurban kanı şifadır.” inancı nedeniyle çocukların alınlarına kan sürmektedirler. Türkmenistan’da gelin eve gelirken kesilen kurbanın kanı onun korunması, yeni yuvasında sağlıklı, bereketli, mutlu bir yaşam sürmesi için alnına sürülmektedir (Kalafat, 2004). Günümüz Irak Türkmenleri ise kurban kanını çocuğun ağzına sürerek tüm dertlerden kurtulacağına inanmaktadırlar (Beydili, 2005). Yine benzer kan sürme ritüeli Kaz Dağı Türkmenlerinde tespit edilmiştir (Duymaz, 2001).

\section{Mülkiyeti korumaya dönük kan ritüelleri}

İnsan için canlı varlığını korumadan sonra bu varlığg sürdürmeye yardımcı olan sahip olduğu ev, arazi, değerli madenler, araçlar vb. nesneler gelmektedir. Bunların başında barındığı ev gelmektedir. Bu nedenle kanda var olduğuna inanılan koruyucu özellikten yararlanılmak istenmiştir. Birçok kültürde temele kan akıtma ritüeli görülmektedir. Bazı araştırmacılara göre bu uygulama Mısır ve Mezopotamya kültürlerine kadar uzanmaktadır. Yine benzer şekilde yaşanılan mekânları kutsamak ve korumak için kan sürme ritüeli tarihte birçok toplumda görülmüştür. Babil'de kurban kanı saray kapılarının üst ve yan sövelerine sürülmüştür (Susa, 2005). Tarihte şehir, saray, mabet, köprü ve ev inşası için kanlı kurban ritüelleri sıkça uygulanmıştır. Bu uygulama ile temel atma esnasında yeraltı tanrılarının nüfuz alanının ihlal edilmesiyle onlardan gelecek zararlardan korunmak ve onları teskin etmek (Brandon, 1970), temel ala- 
nını işgal etmiş kötü ruhları kovmak, temeli kutsallaştırmak, binayı muhtemel tehlikelerden koruma amaçları güdülmüştür. Böylece binanın mülkiyeti ele geçirilmiş ve gelecek olumsuzluklara karşı bina güvenceye altına alınmıştır (Tylor, 1920; H.P.S, 1970). Bu güvence için kanının kullanılması oldukça dikkat çekicidir. Eliade, bu konuyla ilgili olarak evi mikrokozmoz olarak değerlendirir. Ona göre temel atma evrenin yaratılışını simgeler. İnşaatın bir ruha bürünerek hayat sahibi olması için kan gerekir (Eliade, 1991). Bugün kültürümüzde devam eden bir başka korunma amaçlı uygulama ise araçlarla ilgili olarak sürmektedir. Bazı kimseler yeni araç aldıklarında kanlı kurban ritüelini tercih etmektedirler. Bu uygulamanın birçok psikolojik ve sosyolojik boyutları olmakla birlikte bir amacı da korunmaya yöneliktir. Kesilen kurbanın kanı araca sürülerek yaşanması muhtemel kazalardan korunma amaçlanmaktadır (Çetin, 2008).

\section{Arınma Duygusu ve Kan Sembolizmi}

\section{Arınma duygusunun insan hayatındaki yeri}

Suçluluk duygusu evrensel bir olgu olup, hayatın akışı içinde konulan kurallara aykırı davranıldığında hissedilir. Benzer durum dinî hayat için de geçerlidir. Din koyduğu kuralların ihlalini yasaklar ve insanda var olan suçluluk duygusuna günah boyutunu getirir (Hökelekli, 1993). Dinin yasakladığı herhangi bir kuralı ihlal ettiğini fark eden birey günah işlediğini idrak eder (Fırat, 1982). Günah işlediğini fark eden kişide "ben”le arzu edilen "ideal ben" arasında uyum bozulur (Vergote, 1999; Hökelekli, 1993). Pişmanlık, günahtan tiksinme, huzursuzluk ve utanma duyguları kişiyi rahatsız eder (Yapıcı, 1997). Bunların oluşmasında dinî metin- 
lerde günahkâr için vadedilen cezalardan korkma, mükâfatlardan ve sevgiden mahrum olma endişesi oldukça etkilidir (Peker, 2003). Bu durumu birey, Allah'la arasındaki bağın zedelenmesi olarak değerlendirmekte ve onarımını istemektedir. $\mathrm{Bu}$ arzu insanı arınma, tövbe ve hidayete götüren müspet bir arzudur (Hökelekli, 1993).

İnsan işlediği günahın verdiği rahatsızlıktan kurtulmak için arayışa girerek birçok yöntem dener. Tövbe ve çeşitli ibadetler bu arayışa cevap verir. Arınma sürecinde çeşitli kültürlerde benzer nesnelere arındırıcı özellik yüklenerek kullanıldığı görülmekledir. İnsanlık tarihine bakıldığında tuz, su, kül, yăg, kan gibi nesnelere arındırıcı özellikler yüklenmiştir. Arınma yöntemleri ise kültürlere göre farklılık arz etmiştir (Pargament, 1997). Bunların içinde en yaygın kullanılanı su ve kan olmuştur fakat kan sudan daha etkili görülmüştür (Öztürk, 1996).

\section{Arınma amaçlı kan ritüelleri}

Birçok kadim kültürden günümüz kültürlerine kadar kanın arınma arzusu ile ilişkilendirilip kullanıldığı görülmektedir (Bushnell, 1886). Asurlular kesilen oğlak ve kuzu kanlarının günahları temizleyeceğine (Challaye, 1960) inanırlardı. Benzer durum Fenikeliler içinde geçerli idi (Örs, 1966). Afrika kültüründe kanın arındırılıcığına dair inanç ve uygulamalar bulunmaktadır. Günah işlediğine inanan bir kişi bağışlanması için kanlı kurban ritüelini bir yöntem olarak uygulayabilir (Adewale, 1988). Kanın arındırıcılığı antik kültürlerde olduğu kadar ilahi dinlerde de görülmektedir. Bu konuda Yahudilik oldukça dikkat çekicidir. Tevrat’ta geçen “...çünkü kan hayat karşıllğg günah bağışlatır” (Levililer, 17:11) ayetinde kanın arındırıcılığı vurgulanmakta, kansız arınmanın 
gerçekleşmeyeceği belirtilmektedir. Yahudi inançlarına göre kişi kurbanın kanının akışını seyrederken ilahî rahmet olmasaydı günahlarının bedelini kendi kanı ile ödeyeceğini düşünmelidir (D. Y., 1996). Kan sembolizmi konusunda Yahudilerin birçok kültürden etkilendikleri görülmektedir. Babil sürgünü ve Mısır yaşantılarında diğer konularda olduğu gibi kan sembolizmi açısından da etkilenmişlerdir. Ayrıca Orta Doğu'da göçebe bir yaşantı sürmeleri sonucu bu coğrafyadaki kültürlerdeki mevcut kan sembolizminden etkilenmişlerdir. Kanın kutsallığı, Tanrı'nın hakkı olduğu inancı ve kan sürme âdeti Mısır kültüründe bulunmaktaydı. Yine Babil'de kan sürme âdeti ve kanın arındırıcılığına dair inançlar bulunmaktaydı. Benzer durumlar diğer Orta Doğu kültürlerinde de vardı. Yahudi kültürünün en büyük özelliği olan diğer kültürlerden aldığını kendi bünyesine katıp millîleştirmesi kan sembolizminde de görülmektedir.

Kan sembolizminin arınma amaçlı olarak en yaygın kullanıldığı bir diğer ilahî din Hristiyanlıktır. İncil'de geçen “kan dökülmeden günahların bağışlanması mümkün değildir.”(İbranilere Mektup, 9:22) ve “İsa’nın kanı bizi her türlü günahtan temizler.” (I. Yuhanna, 1:7) ayetleri bunu göstermektedir. Görüldüğü gibi kanın arındırıcılığı diğer bütün arındırıcılardan daha üstün görülmüştür. Hristiyanlıkta kan sembolizmi Evharistiya ayinin kalbini teşkil etmektedir. Bu ayin Hz. İsa'nın son akşam yemeğinin hatırasını yâd etmek için gerçekleştirilir. İncil'e göre son akşam yemeğinde Hz. İsa: “Onlar yemek yerlerken ekmek aldl, şükredip kopardı ve onlara vererek dedi: Alın bu benim bedenimdir. Bir kâse şarap aldl, şükrederek onlara verdi; hepsi ondan içti. Onlara bu benim kanımdır.”(Markos, 14:22-24) dedi. Görüldüğü gibi Hristiyan teolojisinde kan sembolizmi merkezî bir konuma sahiptir. 
Kur'an kesilen kurbanda takvanın önemli olduğunu, Allah'a sadece takvanın ulaşacağını, kanının Allah'a ulaşmayacağının ve bazı ayetlerde kanla ilgili olumsuzlukların belirtilmesine rağmen (Kur’an, 2:173; 5:3; 6:145; 16:115) bazı hadislerde ve fikıh kitaplarında kurban kanına önem atfedildiği görülmektedir. Zuhaylî’nin, Tirmizî, Hâkim ve İbni Mace’yi kaynak göstererek aktardığı hadiste şöyle geçmektedir: “...Kurbanın akan kanı yere düşmeden Allah katında yüksek bir makama ulaşır...” (Zuhaylî, 1994). Bazı kaynaklarda ise hadisin kaynağı belirtilmeden "Müminlerin ayırt edici özelliği kurbanın kanı kendi öz kanı olmasıdır.” şeklinde kurban kanının insanın kendi kanı olduğu yönünde rivayetler bulunmaktadır (Gökdemir ve Korkmaz, 1985). Zuhaylî’nin Hâkim, Beyhakî ve Taberanî’den aktardığı bir hadiste Hz. Muhammed kızı Fâtıma’ya şöyle demiştir: "Kalk kurbanının yanında hazır bulun. Çünkü ondan dökülecek ilk damla kan ile tüm günahların bağışlanacaktır (Zuhaylî, 1994). Yine Zuhaylî’nin Hâkim, İbn Mace ve Tirmizî’den aktardığı ve İmam-1 Mâlik'in Muvatta'sında geçen başka bir başka hadiste ise "Âdemoğlu için Kurban Bayramı günlerinde Allah katında kan akıtmaktan daha hayırlı bir amel yoktur.” (Muvatta, Edahi, 3; Zuhaylî, 1994). Bu ve benzeri hadislerin sıhhat derecesi araştırılmalı, dil açısından incelenip tercüme lafzen değil mana dikkate alınarak yapılmalıdır. Ayrıca birçok fikıh kitabında "kurbanda esas olan kan akıtmaktır” (Aydın, 1976; Bardakoğlu ve ark., 2001) gibi ifadelerin kanı öne çıkarması halk arasındaki kadim kültürlerden kalma kan konusundaki inançları kuvvetlendirmektedir.

\section{Sonuç ve Değerlendirme}

Kana yüklenen sembolik anlamlar yalnızca korunma ve arınma ile sınırlı değildir. Bazı tarım toplumlarında bereketi artırıcı olarak görül- 
müş, hasadın bol olması için toprağa karıştırılmış, minnettarlık göstermek için metafizik güçlere sunulmuş, çeşitli büyülerde kullanılmış, ölülerle iletişim aracı sayılmış, bazı mekânlarda var olduğuna inanılan kötü ruhları kovmak için kullanılmıştır. Fakat bu konularda kıyaslama yapma firsatı verecek bilgi birikimimiz olmadığı için çalışmanın dışında tutulmuşlardır. $\mathrm{Bu}$ nedenle araştırmada daha çok farklı kültürlerdeki korunma ve arınma amaçlı benzer ritüellere ağırlık verilmiştir. Görüldüğü gibi farklı kültür ve dinlerde kan ile ilgili benzer inanç ve ritüeller bulunmaktadır.

Kan sembolizminin yaygın olarak görülmesinin altında onun kutsallaştırılması gelmektedir. Farklı kültürlerde kan benzer bir şekilde tanrı/tanrılar ile ilişkilendirilmiştir. Kanın kutsallaştırılmasının bir diğer nedeni ruhun taşıyıcısı sayılmasıdır. Birçok kültürde ruhun metafizikle ilişkili olarak görülmesi kana dair kutsallığı artırıcı bir diğer faktör olmuştur. Özellikle Tevrat’ta canın kanda taşındığını belirten ayet kanın ruh taşıdığı inancını etkilemiştir. Her ne kadar ayette ruh geçmese de ruhun canla beraber olduğunu ve ölümle ayrıldıklarını unutmamalıyı. $\mathrm{Bu}$ inancın yanında kanda bulunduğuna inanılan koruyuculuk ve arındırıcılık ilkel dinler, farklı kadim kültürler, Yahudilik ve Hristiyanlık tarafından desteklenmiştir. Kadim kültürlerden kalan kan sembolizminin görüldüğü bazı alanların Yahudi ve Hristiyan kültürüne dönüşmesi ve bu dinlerin de belli ölçüde benzer inançlara sahip olması kan sembolizmini daha da güçlendirmiştir.

Kan sembolizmini güçlendiren bir diğer ritüel ise kurbandır. Kan sembolizmi kurban ile yakından ilişkili olsa da kurbandan farklıdır. Çünkü kurban kanı dışında bazı kanlar da kutsanmıştır. Ayrıca kurban yal- 
nızca kanlı kurbanlardan ibaret değildir. Birçok kültür ve dinde kanlı kurbanların kansız kurbanlardan üstün sayılması ve zor durumlarda kanlı kurban ritüeline başvurulması kan sembolizmi ile yakından ilişkilidir. Bütün bunların yanında kurbanın diğer hiçbir uzvu için kanda olduğu kadar sembolik anlamlar yüklenmemiştir. Fakat kurbanın kutsal olarak değerlendirilmesi özellikle kurban kanını daha da etkin kılmıştır. Kanlı kurbanların sıklıkla uygulanması çeşitli kültürlerdeki kan sembolizmini güçlendirmiş, güçlü kan sembolizmi de kanlı kurban ritüelinin zor durumlarda daha çok tercih edilmesine neden olmuştur. Kısacası kan ve kurban arasında karşılıklı bir ilişki kurulmuş ve çoğu kültürde kan kurban ritüelinde merkezî konuma sahip sembolik bir nesne olmuştur (Closs, 2003).

Kan sembolizminin güçlenmesindeki bir diğer faktör insan psikolojisindeki korunma ve arınma duygularıdır. Arınma ve korunma duygusunun insanı arayışa itmesi ve kültürlerin kana yükledikleri anlamların bu arayışa cevap vermesi sonucu kan ritüelleri uygulanmıştır Özellikle korunma amaçlı kan ritüelleri diğer ritüelleri de kapsayacak özelliktedir. Çünkü arınma amaçlı uygulamalar bir yerde korunma kapsamındadır. İnsanlar arınarak tanrı/tanrılardan gelecek cezalardan korunmayı veya vicdani rahatsızlığın verdiği sıkıntılardan korunmayı amaçlamışlardır.

Farklı kültürlerde benzer şekilde kanda onda var olduğuna inanılan sembolik anlamlardan yararlanma yoluna gidilmiştir. Sembolik anlamlardan yararlanma yöntemi olarak genel olarak kan sürme yöntemi uygulanmıştır. Bu uygulama ile kanda var olduğuna inanılan metafizik güçlerin sürüldüğü yere aktarılması amaçlanmıştır. $\mathrm{Bu}$ davranışın altında yatan 
psikolojik faktörlerin başında korunma gelmekte diğerleri ise bir şekilde korunma ile ilişkili olup onu takip etmektedirler.

Kana yüklenen sembolik anlamlar kadim kültürlerdeki insan davranışları üzerinde daha etkin olsa da bu etkinin günümüzde değişerek devam ettiği söylenebilir. Bugün günlük hayatımızda kan sembolizmi etkisini sürdürmektedir. Korunma ve arınma amaçlı uygulamaların yanında faşizme varan kan esasına dayalı üstünlük iddiası, kan davası, kan bağı, kan çekmesi, kan kardeşliği, asaletin kan ile taşındığı inancı, akrabalıkların kan esaslı tesis edilmesi, miras taksiminin daha çok kana bağlı kalarak yapılması ve evlenmesi yasak kimselerin kanla belirlenmesi, kan sembolizminin etkisinin devam ettiğini göstermektedir.

\section{Kaynakça}

Adewale, S.A. (1998). Afrika'nın geleneksel dininde kurban. (A. Güç, Çev.). UÜIF Dergisi, 7(7), 587-600.

Allik, J. ve McCrae, R. R. (2004) Escapable conclusions: Toomela (2003) and the universality of trait structure. Journal of Personality and Social Psychology, 87, 261-265.

Alptekin, A. B. (2009). Ceyhun'dan Ceyhan'a evlenme ile ilgili bazı kavramlar. AÜ. Türkiyat Araştırmaları Enstitüsü Dergisi, 39, 307-321.

Arnett, J. J. (2008). The nelected \%95:why American pychology needs to become less American. American Psychologist, 63(7), 602-614.

Ateş, A. O. (1996). İslam'a göre cahiliye ve ehl-i kitab örf ve âdetleri. İstanbul: Beyan Yayınları. 
Aydın, A. A. (1976). Ramazan orucu ve kurban. İstanbul: Kültür Basın Yayın Birliği Yayınları.

Aytaç, Ö. ve İlhan, S. (2007). Girişimcilik ve girişimci kültür: sosyolojik bir perspektif. Selçuk Üniversitesi Sosyal Bilimler Enstitüsü Dergisi, 18, 101-120.

Bardakoğlu, A. ve diğer. (2001). İlmihal I-II (6.baskı). İstanbul: Divantaş Yayınları.

Baskin, J. R. (2007). Menstrual blood. F. Skolnik, (Ed.), Encyclopedia Judica, (2. bask1) içinde. (3, 772). Jerusalem: Keter Publishing.

Bayat, F. (2003). Köroğlu şamandan âşılka, alpten erene. Ankara: Akçă̆ Yayınları.

Bayyiğit, M. (1989). Üniversite gençliğinin dinî inanç, tutum ve davranışları üzerine bir araştırma. Yayınlanmamış doktora tezi, UÜ Sosyal Bilimler Enstitüsü.

Bekki, S. (2011). Bazı halk anlatıları ve dini metinlere göre kahramanların mucizevî (babasız) doğumu. Türk Kültür ve Hacı Bektaşi Veli Araştırma Dergisi, 58, 111-130

Bektaş, Y. (2006). Kültüre duyarlı psikolojik danışma yeterlilikleri ve psikolojik danışman eğitimindeki yeri. Ege Üniversitesi Eğitim Dergisi, 1 (7), 43-59.

Berry, J. W., Poortinga Y. H., Segall M. H. ve Dasen P. R. (2002). Crosscultural psychology: research and application (2.bask1). New York: Cambridge University Press.

Beydili, C. (2005). Türk mitolojisi,ansiklopedik sözlük (1. Bask1). (E. Ercan, Çev.). Ankara: Yurt Kitap Yayınları. 
Brandon, S.G.F. (1970). A dictionary of comparative religion. New York: Charles Scibner's Son.

Budda, H. Ö. (2003). Kurban ve tufan üzerine makaleler. B. Z. Çoban, (Ed.), İstanbul: İnsan Yayınları.

Bushnell, H. (1868). The vicarious sacrifice, grounded in principles of universal obligation. New York: Charles Scibner\&Co.

Certel H. (2003). Din psikolojisi. Ankara: Andaç Yayınları.

Challaye, F. (1960). Dinler tarihi (2.baskı). (S. Tiryakioğlu, Çev.). İstanbul: Varlık Yayınları.

Closs, A. ve Siebeneck, R. (2003). Blood, religious significance of. New Catholic Encyclopedia (2.bask1) içinde (2, 442-444). Washington: Thomson Gale.

Conticelli, V. ve Gabriele, M. (2003). Mikrokozmos’tan makrokozmos’a kanın öyküsü. (A. Kaftan, Çev.). Cogito, 37, 109-129.

Çetin, Ö. (2008). Kurban ile ilgili inanç ve tutumlar. Yayınlanmamış doktora tezi, UÜ. Sosyal Bilimler Enstitüsü.

D. ,Y. (1996). (Sacrifice) In the kabbalah. Encyclopedia Judica içinde(14). Jarusalem: Keter Publishing House.

Daryal, A. M. (1980). Kurban kesmenin psikolojik temelleri. İstanbul: Doğuş Matbaası.

Direk, Z. (2003). Adet kanaması tecrübesi: sınırlar ve ufuklar. Cogito, 37, 251-261.

Durmuş, İ. (2009). Türk kültür çevresinde ant. Milli Folklor, 84, 97-106. 
Duymaz, A. (2001). Kaz dağı ve sarıkız efsaneleri üzerine bir değerlendirme. Balıkesir Üniversitesi Sosyal Bilimler Dergisi, 5, 88102.

Eliade M. (2000). Dinler tarihine giriş. (L. Arslan, Çev.). İstanbul: Kabalcı Yayınları.

Eliade, M. (1994). Ebedi dönüş mitosu.(Ü. Altuğ, Çev.). Ankara: İmge Kitabevi.

Eliade, M. (1991). Kutsal ve dindışı.(M. A. Kılıçbay, Çev.). Ankara: Gece Yayınları.

Erginer, G. (1997). Kurban, kurbanın kökenleri ve Anadolu'da kanlı kurban ritüelleri. İstanbul: Yap1 Kredi Yayınlar1.

Erkal, M. (1984). Sosyal meselelerimiz ve sosyal değişme. Ankara: Mayaş Yayınları.

Eröz, M. (1992). Eski Türk dini (Gök Tanrı inancı) ve alevîlik bektaşilik. İstanbul: Türk Dünyası Araştırmaları Vakfı Yayınları.

Ferm, V. (Ed.). (1945). An Encyclopedia of Religion. (80). New York: Philosophical Library.

Feyizli, T. (1993). İslam'da ve diğer inanç sistemlerinde oruç-kurban. İstanbul: MEB Yayınlar1.

Fırat, E. (1982). Şahsiyet gelişiminde tövbenin fonksiyonu. Yayınlanmamış doçentlik tezi, Ankara Üniversitesi İlahiyat Fakültesi.

Frazer, J. (1991). Altın dal: dinin ve folklorun kökenleri (1). (M. H. Doğan, Çev.). İstanbul.

Fromm, E. (2003). Rüyalar, masallar, mitoslar. (A. Arıtan ve K. H. Ökten Çev.). İstanbul: Arıtan Yayınları. 
Göka, E. (2009). Türklerde liderlik ve fanatizm. İstanbul: Timaş Yayınları.

Gökdemir, A. ve Korkmaz, A. (1985). Yeni Türk Ansiklopedisi içinde (5, 1998). İstanbul: Ötüken Neşriyat.

Gölpınarlı, A. (1995). Vilâyet-name-mânakıb-ı Hünkâr Hacı Bektaş-ı Veli. İstanbul: İnk1lâp Yayınevi.

Güç, A. (2003). Çeşitli dinlerde ve İslâm'da kurban. Bursa: Düşünce Yayınları.

H.P.S. (1970). Sacrifice. Encyclopedia Britannica içinde (19, 864-867) Chigago: Encyclopedia Britannica inc.

Hediel, A. (2000). Enûma Eliş-Babil yaratılış destanı. (İ. Birkan Çev.). Ankara: Ayraç Yayınevi.

Hökelekli, H. (1993). Din psikolojisi. Ankara: T.D.V. Yayınları.

Hökelekli, H. (1983). Ergenlik çă̆ı gençlerinin dinî gelişimi. Yayınlanmamış doktora tezi, Uludağ Üniversitesi İlahiyat Fakültesi.

Incil

Kağıtçıbaşı, Ç. ve Berry, J.W. (1989). Cross-cultural psychology: current research and trends. Annual Review of Psychology, 40, 493-531.

Kağıtçıbaşı, Ç. (2000). Kültürel psikoloji: kültür bağlamında insan ve aile. İstanbul: Evrim Yayınevi.

Kahraman, A. (1965). Dinler tarihi. İstanbul: Sumer Matbaası.

Kalafat, Y. (2004). Karapapah Türkleri. İstanbul Üniversitesi Sosyal Siyaset Konferansları Dergisi, 49, 841-872.

Kan. (1997). Focus Dergisi, Kan Özel Sayısı (12), 60. 
Keith, K. D. (2011). Introduction to cross-cultural psychology. (K. D. Keith, (Ed.), Cross-Cultural Psychoogy içinde (3-20). USA: Blackwell Publishing.

Köknel, Ö. (1995). Korkular. İstanbul: Altın Kitaplar Yayınevi.

Kur'an

Mert, O. (2007). Kemaliye’deki eski Türk izleri: Dilli Vadisi’ndeki petroglif ve damgalar. AÜ Türkiyat Enstitüsü Dergisi, 34, 233-254.

Oman, D. ve Thoresen, C. E. (2005). Do religion and sprituality influence health? R. F. Paloutzian ve C. L. Park, (Ed.). Handbook of the Psychology of Religion and Sprituality içinde (435-460). New York: The Gu1lford Press.

Ökten, K. H. (2003). Yahudilikte ve hıristiyanlıkta kan. Cogito, 37, 133-161.

Öncül, K. (2010). Kültürel süreklilik ve kut taşıyıcılı̆̆ı. Turkish Studies, 5(2), 1279-1287.

Örs, H. (1966). Musa ve Yahudilik, İstanbul.

Özkan, A. R. (2003). Dinlerde kurban kültü. Ankara: Akçağ Yayınları.

Öztürk, N. (1996). İlahi dinlerde yemin kefaret ve kurban. Yayınlanmamış doktora tezi, Selçuk Üniversitesi Sosyal Bilimler Enstitüsü.

Pargament, K. I. (1997). Religious methods of coping: resources for the conservation and transformation of significant. E.P. Shafranske, (Ed.), Religion and the Clinical Practise of Psychology içinde (215-239). Washington: American Psychological Association.

Peker, H. (2003). Din psikolojisi. İstanbul: Çamlıca Yayınları.

Pitirim, A. S. (1994). Çăğdaş sosyoloji kuramları. (M. M. R. Öymen, Çev.). Ankara: Kültür Bakanlığg Yayınları. 
Pritchard, E. E. E. (1956). Nuer religion. New York: Oxford University Press

Roux, J. P. (1987). Blood. L. J. Thomson, (Ed.), Encyclopedia of Religion içinde (2, 985-987). New York: Gale

Roux, J. P. (1987). Blood. M. Eliade, (Ed.), The Encyclopedia of Religion içinde (2, 254-256). New York: Macmillan Company

Roux, J. P. (2005).Orta Asya'da kutsal bitkiler ve hayvanlar. (A. Kazancigil ve L. Arslan, Çev.). İstanbul: Kabalcı Yayınları.

Selçuk, A. (2004). Mersin tahtacılarında kurban fenomeni. İ. Engin ve H. Engin, (Ed.), Alevîlik içinde (299-319). İstanbul: Kitap Yayınevi.

Shiraev, E. B. ve Levy, D. A. (2010). Cross-cultural psychology (4. bask1). Boston: Allyn \& Bacon Publishing.

Spilka, B. (2005). Religious practice, ritüel, and prayer. R. F. Paloutzian ve C. L. Park, (Ed.), Handbook of the psychology of religion and sprituality içinde (365-378). New York: The Gu1ford Press

Susa, A. (2005). Tarihte araplar ve yahudiler iki İbrahim, iki Musa, İki Tevrat. İstanbul: Selenge Yayınları.

Şentürk, H. (1997). Din psikolojisi. Konya: Esra Yayınları.

Tezcan, M. (1991). Toplumsal ve kültürel değişme (2.bask1). Ankara: AÜ Eğitim Bilimleri Fakültesi Yayınları.

Tevrat

Triandis, H. C. (2007). Culture and psychology: a history of the study of their relationship. S. K. D. Cohen, (Ed.), Cultural Psychology içinde (59-76). New York: The Guildford Press. 
Turan, O. (1993). Türk cihan hâkimiyeti mefkûresi tarihi. İstanbul: Boğaziçi Yayınları.

Tylor, E.B. (1920). Primitive culture. USA: Holt.

Vergote, A. (1999). Din, inanç ve inançsızlık. (V. Uysal, Çev.). İstanbul: Marmara Üniversitesi, İlahiyat Fakültesi Vakfi Yayınları.

Yaparel, R. (1987). Yirmi-kırk yaşlar arası kişilerde dinî hayat ile psikososyal uyum arasındaki iliş̧i üzerine bir araştırma. Yayınlanmamış doktora tezi, AÜ Sosyal Bilimler Enstitüsü.

Yapıcı, A. (1997). İslam'da tövbe ve dinî yaşayıştaki rolü. İstanbul: Beyan Yayınları.

Zuhaylî, V. (1994). İslâm fikıh ansiklopedisi (4) (A. Efe ve diğer. , Çev.). İstanbul: Feza Yayınları. 